\title{
Breast Cancer Pathologic Primary Tumor TNM Finding v8
}

National Cancer Institute

\section{Source}

National Cancer Institute. Breast Cancer Pathologic Primary Tumor TNM Finding v8. NCI Thesaurus. Code C139411.

A pathologic finding about one or more characteristics of breast cancer, following the rules of the TNM AJCC V8 classification system as they pertain to staging of the primary tumor. Lobular carcinoma in situ (LCIS) is a benign entity and is removed from TNM staging in the AJCC Cancer Staging Manual, 8th Edition. (from AJCC 8th Ed.) 